\title{
Gender pay gap in salary bands among employees in the formal sector of South Africa
}

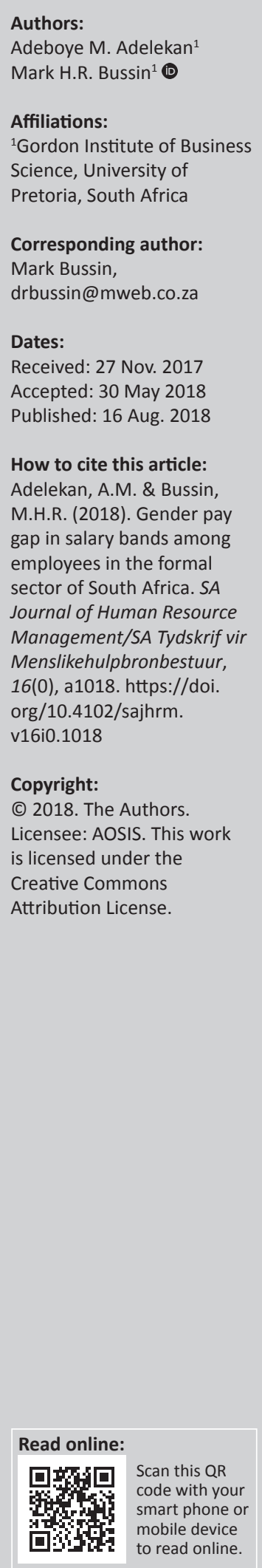

Orientation: The gender pay gap is a worldwide challenge that has persisted despite political will and interventions. Comparably qualified women performing similar work as men continue to earn less. There are conflicting views in the literature regarding the status of the gender pay gap.

Research purpose: The purpose of the study was to determine status of the gender pay gap among employees in the same salary band and to establish whether men and women receive similar pay for similar work in the study population.

Motivation for study: The status of the gender pay gap would establish the progress made towards closing the gap and guide necessary adjustments to interventions.

Research approach/design and method: A quantitative analysis was conducted on the pay information of 217902 employees collected in a survey from over 700 companies, across 10 job families and 6 industries.

Main findings: Men's pay was consistently higher than that of women in all salary bands except at the 75th and 95th percentile in sub-bands B-lower and B-upper and 25th percentile in sub-band E-upper. The gender pay gap ranged from $8 \%$ in band A to $27.1 \%$ in sub-band F-upper. The gaps observed in the salary bands were statistically significant $(p<0.0001)$ except in sub-band E-upper, F-lower and F-upper, indicating convergence towards similar pay for similar work at senior to top management levels. Women were under-represented in all salary bands with the lowest presence in band F, especially sub-band F-upper. Gender, race, job family and industry have a significant effect on income earned in the study sample.

Practical/managerial implications: Government's efforts seemed to have produced minimal results as women are represented in all job families, industries and salary bands. The pay of men and women in senior and top management levels was similar. However, more still needs to be done to achieve the $50 \%$ target representation of women in senior management and close the gap at all levels.

Contribution/value-add: The number of women at management levels is still very low when compared to their male counterparts. However, the gender pay gap in senior to top management positions are converging towards similar pay for work of similar value.

\section{Introduction}

\section{Key focus of the study and background}

The pay of some women remains less than that of men, even when the women have the same level of education or perform work of the same value as men (Bosch, 2015; Bussin \& Nienaber, 2015; Rollor, 2014; Witkowska, 2013). Despite government interventions and improvement in the profile of women in terms of education and increased labour force participation, even at management level, the gap in the pay between women and men seems to have persisted (Misra \& Strader, 2013). This is worrying in light of the Sustainable Development Goals aimed at achieving gender equality and empowerment of all women and girls.

There are contrasting reports on the status of the gender pay gap in South Africa. Steyn (2012) documented cases of contrasting reports, including one that stated that the gender pay gap increased over the period 1995-2005 and another that stated that the gender pay gap increased from 31\% to 38\% between 2001 and 2005. However, data from the South Africa Department of Labour suggested that the gap declined from 41\% to 25\% in the period 1995 to 2005 and another report stated that the gap has narrowed since 2000. Kahn and Motsoeneng (2014) reported a gender pay gap of $27 \%$ for the public sector and $35.5 \%$ for the private sector. A report by Bussin 
and Nienaber (2015) indicated an estimated pay gap of 15\%. Finally, a study conducted by Steyn and Jackson (2015) indicated no statistically significant difference in pay between men and women.

\section{Trends from the research}

The gender pay or wage gap refers to the difference between men's pay and women's pay as a percentage of men's pay (New Joint Committee for Higher Education Staff (JNCHES), 2011). It is referred to as a permanent feature, found in all periods and in all countries, including developed and developing countries (Aláez-Aller, Longás-García, \& UllibarriArce, 2011; Fransen, Plantenga, \& Vlasblom, 2012). Gender inequality is well documented, and its effects manifest in the form of disparity in pay, human capacity development and access to opportunities (Wekwete, 2014). This phenomenon is as old as ancient Rome, when women were not allowed to vote or hold public office. Furthermore, when women are employed, they are paid less than men, because they are not regarded as breadwinners (Bussin \& Nienaber, 2015).

Previously, the gap was attributed to women not being suitably qualified in terms of education and work experience (Fransen et al., 2012). Others attributed the gap to women's choice of occupation and their inability to negotiate pay at the comparable levels (Travis, 2014). Discrimination is also said to have played a role in creating and propagating the gender pay gap (Arvanitis, Stamatopoulos, \& Thalassinos, 2009; Steyn \& Jackson, 2015; Witkowska, 2013). The gender pay gap has the potential to impact negatively on women's ability to live decent lives, provide for their families and be financially secure at retirement (Belgorodskiy et al., 2012; Witkowska, 2013). It is the reason for employees' resignation, deviant practices and psychological disengagement at work (Bosch, 2015; Bussin \& Nienaber, 2015). It could also impact negatively on the productivity of the nation if women, who constitute over $50 \%$ of the adult population, continue to be marginalised and prevented from contributing to the country's economic opportunities and growth (Kahn \& Motsoeneng, 2014; New-JNCHES, 2011; Steyn, 2012). The situation is further complicated by contradictory views reported in the literature on the status of the gender pay gap (Steyn, 2012). Gender equity is needed for self-actualisation, maximum development and citizens to contribute optimally to the growth and development of the country (ArnaniaKepuladze, 2012).

The current status of the gender pay gap is not certain, making it very difficult to chart the way forward and measure progress towards the goal of gender pay equity for work of equal value. Hence, the proposed study will focus on determining the status of gender pay gap in a sample of the South Africa population.

\section{Research objectives}

The purpose of the research study was to establish the status of the gender pay gap among employees doing similar work, with the hope of generating evidence that could lead to policy revision and strengthening of the interventions being implemented. This was achieved by interrogating the pay information of employees in salary bands and investigating the effects of associated independent variables on income. The research questions were as follows:

- What is the gender pay gap in salary bands or among employees performing similar work?

- What is the effect of selected variables (e.g. gender, race, job family and industry) on the gender pay gap in the study sample?

\section{Synthesis and critical evaluation of the literature}

The literature review was focused on development of the key concepts of the gender pay gap and interventions aimed to close the gap. The literature review is in four parts including gender evolution, the root cause of the gender pay gap, an overview of gender pay gap and responses to the gender pay gap.

\section{Gender evolution}

'Gender' refers to societal roles (e.g. men as the head of families and breadwinners and women if married as the primary caregiver to their husbands, children and extended family members), while 'sex' refers to a person's biological classification. Gender is related to dynamic power relationships between men and women (Bendl \& Schmidt, 2013; de Jonge Oudraat, 2013). Gender can be defined as the social and cultural differences between men and women with regard to relationship, diversity, community roles, and power relationships (Zebracki, 2014). The power relationship determines the gender roles and expectations of society (de Jonge Oudraat, 2013). The term has been used in the literature since the late 1960s (Zebracki, 2014).

Zebracki (2014) argued that the topic of gender has evolved over the last 40 years. The first shift in the role of women was from that of carer to that of carer and wage worker. Next was the shift from the emphasis on the differences between women and men to an emphasis on diversity among women. The third was the evolution in terminology related to gender, including 'equal opportunity', 'gender sensitivity' and 'gender mainstreaming' (Zebracki, 2014). Rego Diaz (2013) recounted the evolution in the debate for equal gender rights as having included the demand for women's empowerment, women's advancement and equality, and gender mainstreaming.

The terms 'gender sensitivity' and 'gender mainstreaming' have become very important, because of the unique needs of women and men. There is a distinct advantage to gender mainstreaming over approaches proposed and implemented previously (Zebracki, 2014). This view is supported by Bendl and Schmidt (2013), who argued that, while gender mainstreaming focuses on transformation of institution, systems and standard associated with masculinity and femininity, the previous concepts were not as comprehensive. 
These include 'equal opportunity', which focused on individual rights, and 'positive action', which focused on the special needs and disadvantages of a group (Bendl \& Schmidt, 2013).

\section{The root cause of the gender pay gap}

Gender inequality is as old as human existence (Bussin \& Nienaber, 2015); it has its roots in religion and has been propagated by cultures where women are considered the weaker sex and men are viewed as the head of the family (Kahn \& Motsoeneng, 2014; Wekwete, 2014; Witkowska, 2013). Stereotypes and perceived gender roles have been passed from generation to generation through culture and ways in which parents interact with their children (Nadler \& Stockdale, 2012). The inculcated gender role predisposes women to certain career capital development and choice of profession (Nadler \& Stockdale, 2012). This could explain the reason why some women are submissive to and dependent on men. It could also play a role in the inability of some women to negotiate equal pay for work of the same value (Travis, 2014).

Gender inequality and the pay gap favours men (Steyn \& Jackson, 2015). Female children appear to be disadvantaged from birth, as they are perceived as the weaker sex and not given the same level of education as male children (Nadler \& Stockdale, 2012). In African culture, among others, a male child is valued more. This could be because a male child remains in the family, keeps the family name and becomes a breadwinner (Bussin \& Nienaber, 2015; Kahn \& Motsoeneng, 2014), while when a female child marries she joins another family. Many of these socio-cultural beliefs, norms and practices have changed, yet evidence of the stereotype remains (Wekwete, 2014). Female children now have access to education and are encouraged to pursue professions in science, mathematics, technology, engineering and medicine, which were previously dominated by men (Jefferson \& Austen, 2015; Xu, 2015).

Low human capacity development among women, relative to that of men, is one of the reasons postulated for women earning less than men (Addabbo \& Favaro, 2011). The low human capacity in terms of education and work experience limits women's access to high-paying jobs (Fransen et al., 2012; Steyn \& Jackson, 2015). Furthermore, women are affected by discrimination, which hinders their ability to compete for employment, negotiate optimum payment and gain promotion (the 'glass ceiling' and 'sticky floor' phenomena) (Aláez-Aller et al., 2011; Arulampalam, Booth, \& Bryan, 2007; O'Dorchai, 2011). The perception of the role of women being predominantly to run the home, bear children and care for them has caused women to seek employment based on proximity and convenience (Blau \& Kahn, 2007; Kahn \& Motsoeneng, 2014; Steyn \& Jackson, 2015). This may result in women accepting low-paying, informal jobs, as well as a reduced ability to negotiate an optimum salary (Wekwete, 2014). In order to achieve gender equality and provide women with the opportunity to take up better jobs, discriminatory practices and social norms, traditions and laws have to be addressed (Luci, Jütting, \& Morrisson, 2012).

\section{Overview of gender pay gap trends and status}

An article published by Aláez-Aller et al. (2011) showed that the gender pay gap in 13 European countries ranged from $3.0 \%$ (in Denmark) to $15.0 \%$ (in the UK [United Kingdom]). The view that the pay gap in the public sector is narrower than in the private sector was supported by New-JNCHES (2011), which reported a $14.6 \%$ gender pay gap among fulltime employees in the UK's public sector, compared to $21.6 \%$ in the private sector.

Bhorat and Goga (2013) reported an average gender pay gap of $17.5 \%$ for 27 countries in the EU and $23.2 \%$ for Germany in 2008. In a study on the pay gap in the Information Communication and Technology (ICT) sector, Belgorodskiy et al. (2012) reported a female-to-male pay ratio of 0.77 (a $23.0 \%$ gap) for New Zealand and a 0.64 ratio (a 36.0\% gap) for the UK. The difference in these pay gaps was because New Zealand has a higher percentage $(25.0 \%)$ of women employed full-time in ICT, compared to $15.0 \%$ in the UK. Fransen et al. (2012) reported a pay gap of $20.0 \%$ for the Netherlands and an average of $17.0 \%$ for Europe.

Casale and Posel (2011) and Steyn (2012) confirmed the existence of a gender pay gap in South Africa. The percentage of women in the labour force in South Africa has increased from $48.4 \%$ to $61.7 \%$ since the 1980 s. The gender pay gap was shown to have increased between 1995 and 2005 and narrowed since 2000. Discrimination was shown to play a pivotal role in accounting for the pay differences. Furthermore, the gender pay gap could be a result of women's level of education, field of study, career choices, work patterns, their marital and family status and their union affiliation (Steyn, 2012).

\section{Responses to the gender pay gap}

Gender equality as a policy objective has gained universal acceptance (Witkowska, 2013). The promotion of gender equality and equal pay for work of equal value is high on the agenda of the UN and countries around the world. This has led to the development of many related initiatives, including legislation, conventions, policies and programmes.

Legal framework: Some of the international conventions and declarations ratified by nations in order to achieve gender equality are as follows: the International Labour Organization's Discrimination (Employment and Occupation) Convention of 1958 (No. 111); the Equal Remuneration Convention of 1951 (No. 100); the Universal Declarations of Human Rights (1948); the European Social Charter (1996); the European Equal Pay Directive (1975); and the UN Sustainable Development Goals. South Africa's political will and commitment to gender equality manifests in the ratification of these conventions and declarations and by developing legislation and policies to implement them (Bussin \& Nienaber, 2015). Examples of such legislation include the constitution of the Republic of South Africa (Act 108 of 1996), the White Paper on the Transformation of the Public Service 1995, which expresses the desire of government for $50.0 \%$ representation of women in senior management positions; the White Paper on Affirmative 
Action in the Public Service 1998; the Employment Equity Act 47 of 2013, the Basic Conditions of Employment Act 75 of 1997; the Domestic Violence Act 116 of 1998 and the Promotion of Equity and Prevention of Unfair Discrimination Act 4 of 2000 (Kahn \& Motsoeneng, 2014).

Blau and Kahn (2007); Drolet and Mumford (2012); and Mandel and Semyonov (2014) noted a decline in the pay gap in industrialised countries and attributed the achievement to the introduction of anti-discrimination legislation, the high educational achievement of women, increased participation in traditionally male-dominated occupations and the availability of diverse opportunities. The labour force participation of women with university degrees has improved to a level comparable to that of men, indicating the importance of the human capital development of women in achieving gender pay equity (Aláez-Aller et al., 2011).

\section{Research design \\ Research approach}

The research objective was achieved with descriptive study design and quantitative analysis.

\section{Research method}

The pay information used was obtained from 21st Century (Pty) Ltd, one of the largest reward consultancies in Africa. The pay information was obtained in a survey from respondents in over 700 companies, spread across 10 job families in 6 industries. The job families included compliance and risk; executive management; financial and accounting; human capital; information technology; logistics and procurement; marketing and sales; operational; secretarial; and technical and specialist. The industries represented in the study were extractive; transformative; distributive services; producer services; social services; and personal services. Descriptive and inferential analysis was conducted on the pay information to establish status of gender pay in the salary bands. Also, the effect of variables - race, gender, job family and industry - on the guaranteed package was assessed with a regression analysis.

\section{Research participants}

The sample consisted of women and men, 18 years and older, employed in the formal sector, mostly made up of companies in the private sector, which had participated in the survey conducted by 21st Century. The database consisted of 264660 respondents' pay information. However, analysis was conducted on 217902 of the respondents, who had a complete set of information.

\section{Research design}

The research is a cross-sectional or snap-shot study of the difference between pay earned by men and women employed in the formal sector. This is because the data used represent the pay situation at a point in time. Quantitative methods were used for this research study, because it was aimed at answering the question 'how much', which is best answered using quantitative methods (McCusker \& Gunaydin, 2015). Moreover, the research was a descriptive study, because the researcher did not influence the study conditions or sample in any way but only described the pay status observed (Creswell, 2013; Saunders \& Lewis, 2012). Furthermore, the analysis conducted was a secondary data analysis because the data used had been collected in a routine survey for purposes other than the present study.

\section{Research measures}

The unit of analysis was gender pay, as the aim was to establish the status of the gender pay gap and describe the extent of the gap. 'Pay' or 'income' refers to the 'guaranteed package' of the respondents. The guaranteed package is the basic salary plus the benefits received by an employee per year. This includes car benefits, which could be in form of the cost to company for providing a company car or a car allowance plus reimbursement. Other benefits include housing, low-cost loans, club fees, professional fees, subscriptions, cell phone allowance, computer allowance and other similar benefits (Bussin, Nicholls, \& Nienaber, 2016; Twenty-first-(21st)-Century-Pay-Solutions, 2016).

\section{Statistics analysis}

The pay information was received in a Microsoft Excel spreadsheet and Stata 14.1 (StataCorp, 2015) statistical software was used for the analysis. Two types of analyses were conducted, including descriptive and inferential statistics. The descriptive analysis was performed to gain an overview of the study sample in terms of all the variables measured, while the inferential statistics established whether the observed gender pay gap was because of chance. The data was processed before analysis was conducted by checking for missing values and cleaning the data. The values in each variable were examined and classified as either categorical or numerical before coding was performed as applicable. Participants with missing data were not included in the analysis. The treatment was justified because the missing data appeared to be missing completely at random. This is because the variable guaranteed package, which is the most sensitive information, had only two (less than 1\%) missing values, while the next most sensitive variable, race, had $11.4 \%$ missing values. Missing values of between $5 \%$ and less than $20 \%$ are considered small and could be deleted without risk of introducing bias into the study (Saunders et al., 2006).

The Shapiro-Wilk test of normality established that the guaranteed packed distribution was heavily skewed. Also, the data did not achieve normality after various forms of transformation processes had been performed. This implied that a parametric test, like the $t$-test, could not be used. Hence, a non-parametric or distribution free test - the MannWhitney rank-sum test - was used for the inferential analysis of the gender pay gap. The measurement was conducted at a 
$95 \%$ confidence level and a $p$-value $\leq 0.05$ signified statistical significance. In addition, the median not biased by skewness of data was used as the measure of summary or central tendency for the pay distribution and in the calculations of the gender pay gap (Pagano, Gauvreau, \& Pagano, 2000; Rosner, 2015; Wegner, 2012).

The gender pay gap was calculated at several points in the guaranteed package distribution within each salary band to provide a detailed picture of the status and the trend of the gap. The points were p10, p25, p50, p75 and p95 (This refers to the percentiles in a pay range, i.e. 10th percentile, 25 th percentile, 50 th percentile, 75 th percentile and 95th percentile). The salary bands contained six categories: A, B, C, D, E and F. The Peterson rule was applied in merging sub-grades of $\mathrm{A}$ to form band $\mathrm{A}$ and sub-grades of bands $\mathrm{B}$ to $\mathrm{F}$ to form lower and upper sub-bands. The pay brackets or salary bands were established based on the number and complexity of decisions associated with the job. The respondents were allocated to the band that fitted their level of responsibility. Band A corresponds to employees with basic skills, band B to semi-skilled, band C to skilled, band D to middle management, band $\mathrm{E}$ to senior management and band $\mathrm{F}$ to top management (Steyn \& Jackson, 2015; Twenty-first-(21st)-Century-Pay-Solutions, 2016). Therefore, the salary bands are a good proxy for similarity of work or level of responsibility at work. Furthermore, test of association and regression analysis was conducted to determine the influence of factors such as race, gender, job family and industry on the guaranteed package, categorised into four groups based on quartiles or percentiles (Creswell, 2013; Rosner, 2015; Zikmund, Babin, Carr, \& Griffin, 2013): Group 1 (pay $\leq$ Q1 or p25); Group 2 (pay $>$ Q1 or p25 and $\leq$ Q2 or p50); Group 3 (pay $>$ Q2 or p50 and $\leq$ Q3 or p75); and Group 4 (pay $>$ Q3 or p75).

\section{Results}

\section{Descriptive and inferential statistics}

\section{Demographics}

The analysis was conducted on the pay information of the 217902 respondents with complete information. This consisted of 75373 (34.59\%) women and 142529 (65.41\%) men. When disaggregated by race, it consisted of 141465 (64.92\%) black people, 44181 (20.28\%) white people, 21140 (9.70\%) people of mixed race and 11116 (5.10\%) Asian or Indian people (Table 1). When further disaggregated by gender, the black people consisted of 45483 women and 95982 men, the white people consisted of 16178 women and 28003 men, the people of mixed race consisted of 8931

TABLE 1: Population frequency by gender and race.

\begin{tabular}{|c|c|c|c|}
\hline \multirow[t]{2}{*}{$\overline{\text { Race }}$} & \multicolumn{2}{|c|}{ Gender } & \multirow[t]{2}{*}{ Total } \\
\hline & Female & Male & \\
\hline Black African & 45483 & 95982 & 141465 \\
\hline White & 16178 & 28003 & 44181 \\
\hline Mixed race & 8931 & 12209 & 21140 \\
\hline Indian & 4781 & 6335 & 11116 \\
\hline Total & 75373 & 142529 & 217902 \\
\hline
\end{tabular}

women and 12209 men and the Asians and Indian people consisted of 4781 women and 6335 men (Table 2). The proportion of respondents in the lowest to highest salary band included $5.73 \%$ in $\mathrm{A} ; 41.66 \%$ in $\mathrm{B} ; 37.30 \%$ in $\mathrm{C} ; 13.74 \%$ in $\mathrm{D} ; 1.45 \%$ in $\mathrm{E}$ and $0.13 \%$ in $\mathrm{F}$. A majority of participants within each salary band were in the lower sub-band. Men were in the majority in all salary bands (Table 3 ).

\section{Guaranteed package and pay gap}

The guaranteed package in the study sample ranged from R550.00 to R7 690 888.00. Men's pay was consistently higher than that of women in band A, sub-bands B-lower and B-upper (except at the 75th and 95th percentiles for both subbands), sub-bands C-lower and C-upper, sub-bands D-lower and D-upper, sub-bands E-lower and E-upper (except at the 25 th percentile) and sub-bands F-lower and F-upper.

Results of the rank-sum test indicated that the gender pay gap is statistically significant with a $p<0.0001$ in band A, sub-bands B-lower and B-upper, sub-bands C-lower and C-upper, sub-bands D-lower and D-upper, and sub-band E-lower (Table 4). However, there was no significant difference in the pay of men and women in sub-band E-upper or sub-bands F-lower and F-upper, with $p$-values of 0.1227 ,

TABLE 2: Population frequency by salary band.

\begin{tabular}{lccc}
\hline Paterson salary band & Freq. & Per cent & Cum. \\
\hline A & 12483 & 5.73 & 5.73 \\
BL & 65043 & 29.85 & 35.58 \\
BU & 25741 & 11.81 & 47.39 \\
CL & 54578 & 25.05 & 72.44 \\
CU & 26692 & 12.25 & 84.69 \\
DL & 23993 & 11.01 & 95.70 \\
DU & 5942 & 2.73 & 98.43 \\
EL & 2476 & 1.14 & 99.56 \\
EU & 670 & 0.31 & 99.87 \\
FL & 228 & 0.10 & 99.97 \\
FU & 56 & 0.03 & 100.00 \\
\hline Total & $\mathbf{2 1 7 9 0 2}$ & $\mathbf{1 0 0 . 0 0}$ & 1.00 \\
\hline
\end{tabular}

Freq., frequency; Cum., cumulative.

A, basic skill level; BL, semi-skilled level; BU, semi-skilled supervisory level; CL, skilled level; $\mathrm{CU}$, skilled level supervisory; DL, middle or tactical management level; DU, middle or tactical supervisory level; EL, senior management level; EU, senior management supervisory level, FL, top management; FU, top management supervisory level.

TABLE 3: Population frequency by salary band and gender.

\begin{tabular}{|c|c|c|c|}
\hline \multirow{2}{*}{$\begin{array}{l}\text { Paterson salary } \\
\text { band }\end{array}$} & \multicolumn{2}{|c|}{ Gender } & \multirow[t]{2}{*}{ Total } \\
\hline & Female & Male & \\
\hline $\bar{A}$ & 3669 & 8814 & 12483 \\
\hline $\mathrm{BL}$ & 17270 & 47773 & 65043 \\
\hline$B U$ & 9413 & 16328 & 25741 \\
\hline $\mathrm{CL}$ & 23512 & 31066 & 54578 \\
\hline $\mathrm{CU}$ & 9790 & 16902 & 26692 \\
\hline $\mathrm{DL}$ & 8955 & 15038 & 23993 \\
\hline DU & 1879 & 4063 & 5942 \\
\hline EL & 684 & 1792 & 2476 \\
\hline EU & 157 & 513 & 670 \\
\hline $\mathrm{FL}$ & 42 & 186 & 228 \\
\hline $\mathrm{FU}$ & 2 & 54 & 56 \\
\hline Total & 75373 & 142529 & 217902 \\
\hline
\end{tabular}

A, basic skill level; BL, semi-skilled level; BU, semi-skilled supervisory level CL, skilled level; $\mathrm{CU}$, skilled level supervisory; DL, middle or tactical management level; DU, middle or tactical supervisory level; EL, senior management level; EU, senior management supervisory level; $\mathrm{FL}$, top management; FU, top management supervisory level. 
TABLE 4: Assessment of guaranteed package trend per salary band

\begin{tabular}{|c|c|c|c|c|c|c|c|c|}
\hline Salary band & Gender & Mean & p10 & p25 & p50 & p75 & p95 & $p$ \\
\hline \multirow[t]{2}{*}{ A } & Female & 94911.6 & 43004.0 & 61556.0 & 103998.0 & 122781.0 & 133752.0 & $<0.0001$ \\
\hline & Male & 104184.9 & 47814.0 & 81968.0 & 113039.5 & 132042.0 & 141555.0 & \\
\hline \multirow[t]{2}{*}{ B-lower } & Female & 134903.0 & 54000.0 & 81888.0 & 132685.0 & 171014.0 & 260027.0 & $<0.0001$ \\
\hline & Male & 144054.9 & 76220.0 & 124782.0 & 139643.0 & 168625.0 & 234762.0 & \\
\hline \multirow[t]{2}{*}{ B-upper } & Female & 206535.2 & 123420.0 & 157797.0 & 195596.0 & 254824.0 & 312983.0 & $<0.0001$ \\
\hline & Male & 214043.7 & 144412.0 & 177736.0 & 202514.0 & 251829.0 & 310123.0 & \\
\hline C-lower & Male & 324748.5 & 190000.0 & 260641.0 & 329092.0 & 384791.0 & 488301.0 & \\
\hline \multirow[t]{2}{*}{ C-upper } & Female & 436404.1 & 291865.0 & 377582.0 & 425265.0 & 503770.0 & 633248.0 & $<0.0001$ \\
\hline & Male & 476040.4 & 338542.0 & 396825.0 & 460845.5 & 557771.0 & 678162.0 & \\
\hline \multirow[t]{2}{*}{ D-lower } & Female & 626769.6 & 390156.0 & 477000.0 & 618030.0 & 751579.0 & 954000.0 & $<0.0001$ \\
\hline & Male & 690669.3 & 432000.0 & 524160.0 & 680883.5 & 828863.0 & 1048244.0 & \\
\hline \multirow[t]{2}{*}{ D-upper } & Female & 941562.6 & 642037.0 & 767634.0 & 942004.0 & 1084458.0 & 1360000.0 & $<0.0001$ \\
\hline & Male & 1025837.0 & 708000.0 & 861553.0 & 1022314.0 & 1179870.0 & 1440358.0 & \\
\hline E-lower & Male & 1372581.0 & 946099.0 & 1133239.0 & 1341645.0 & 1566815.0 & 2000004.0 & \\
\hline \multirow[t]{2}{*}{ E-upper } & Female & 1804075.0 & 1195498.0 & 1521900.0 & 1791000.0 & 2100000.0 & 2515261.0 & 0.1227 \\
\hline & Male & 1888222.0 & 1260000.0 & 1520402.0 & 1836400.0 & 2193800.0 & 2845515.0 & \\
\hline \multirow[t]{2}{*}{ F-lower } & Female & 2298798.0 & 1474280.0 & 1808603.0 & 2351606.0 & 2815338.0 & 3382656.0 & 0.3131 \\
\hline & Male & 2427518.0 & 1600000.0 & 1980601.0 & 2400565.0 & 2841652.0 & 3710000.0 & \\
\hline \multirow[t]{2}{*}{ F-upper } & Female & 2937805.0 & 2370375.0 & 2370375.0 & 2937805.0 & 3505234.0 & 3505234.0 & 0.0851 \\
\hline & Male & 4240381.0 & 3031657.0 & 3392604.0 & 4087615.0 & 4888798.0 & 7057320.0 & \\
\hline
\end{tabular}

$p$, $p$-value: $\mathrm{p}$, percentiles in a pay range.

0.3131 and 0.0851 , respectively. The gender pay gap based on the median values in the salary bands (Table 4 ) is as follows: A $(8.0 \%)$, B-lower (5.0\%), B-upper (3.4\%), C-lower $(8.8 \%)$, C-upper (7.7\%), D-lower (9.2\%), D-upper (7.9\%), E-lower (5.3\%), E-upper (2.5\%), F-lower (2.0\%) and F-upper (27.1\%).

\section{Number of women relative to men across salary bands}

The number of women to men decreased in bands B-lower, C-upper and from D-upper to F-upper (see Figure 1). However, there was increased representation of women from B-lower to C-lower, as well as from C-upper to D-lower, which corresponded to respondents who were semi-skilled, skilled and in middle management, respectively, on the salary scale.

Furthermore, there was increased representation of men from D-lower to F-upper, which corresponded to respondents in middle management, senior management and top management, respectively (Twenty-first-(21st)-Century-PaySolutions, 2016). Women were under-represented in all salary bands, with the highest representation $(43.1 \%)$ in C-lower and the lowest (3.6\%) in F-upper. The second-lowest representation of women was $18.4 \%$, in F-lower.

\section{Test of independence and regression analysis}

The chi-square test showed statistically significant association between guaranteed package and race, gender, job family and industry with a $p<0.0001$ (Figure 2). Also, the regression model was found to be statistically significant in predicting guaranteed package when these variables were used. However, the model was only able to explain about $44.0 \%$ of the variance of the guaranteed package. Gender, race, industry and job family (with the exception of Human Capital) were all statistically significant in predicting the guaranteed package in the study sample.

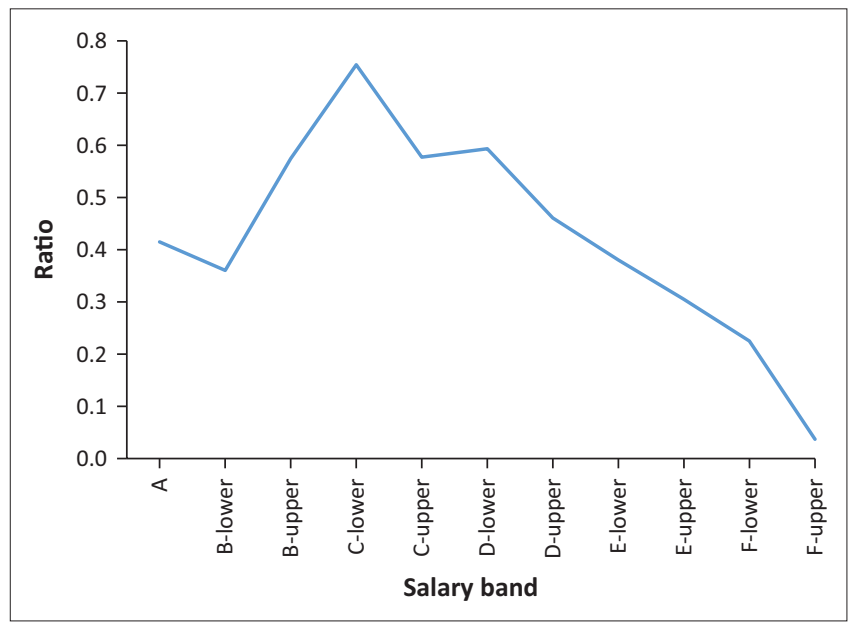

FIGURE 1: Trend of ratio of women to men by salary band.

The model predicted that men's guaranteed package was higher than that of women by an average of R15 125.33. The gender reference point was female. With regard to race, the reference point was black people, and the model predicted that the guaranteed package for black people was less than that of the following groups: white people, by R193 330.40; people of mixed race, by R21 312.04; and Asian and Indian people, by R149 165.40. This placed the race category white people as the highest-earning group in the study sample, followed by Asian and Indian people, people of mixed race and black people.

Also, the predicted average earning of respondents in a job category relative to compliance and risk was as follows: executive management earn more by R1 060 264.00; financial and accounting earn less by R121 840.50; human capital earn more by R5816.65; information technology earn more by R23 888.77; logistics and procurement earn less by R151 964.40; marketing and sales earn less by R170 745.00; operational earn less by 


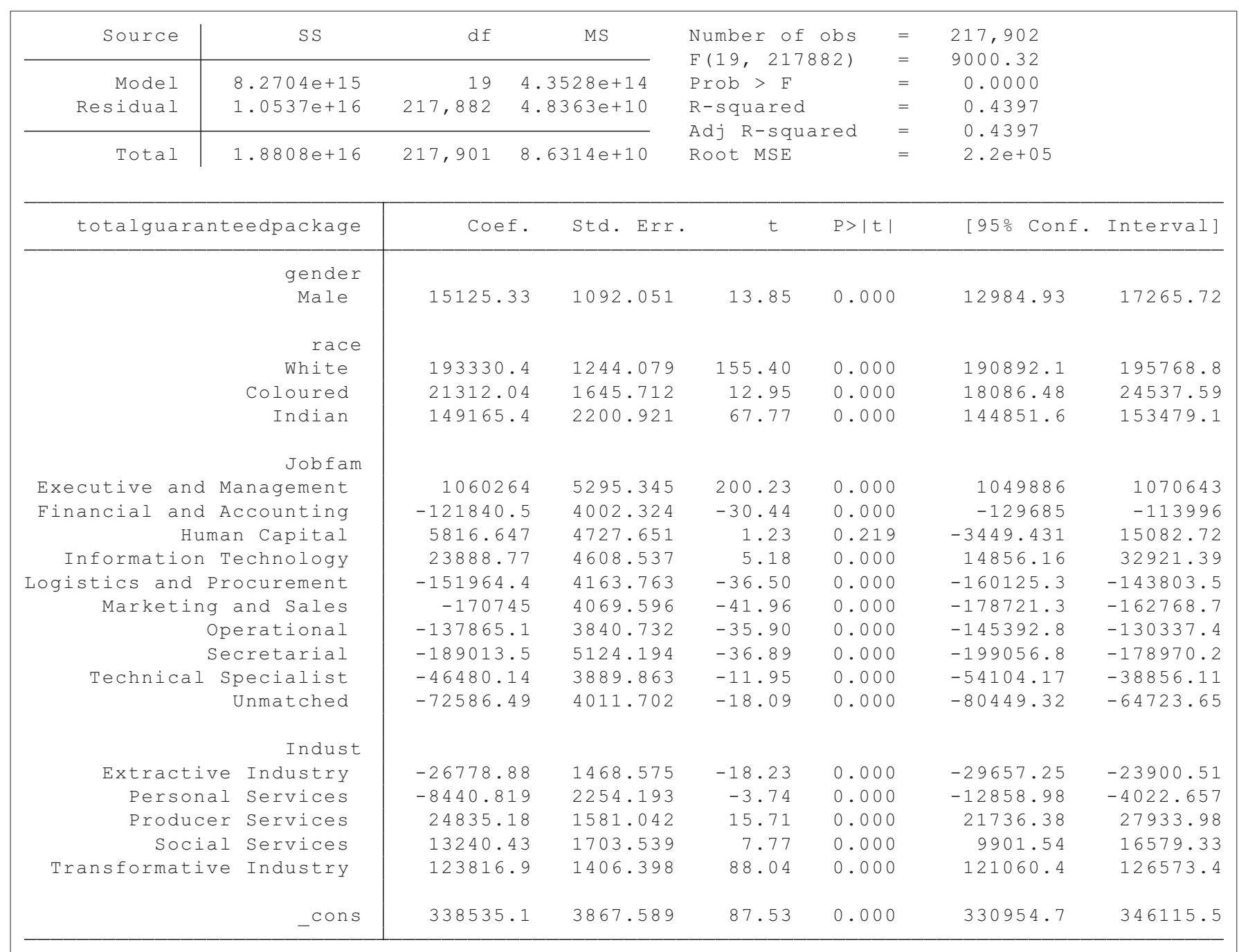

SS, sum of squares; df, degrees of freedom; MS, mean square; obs, observations; Prob, probability; Adj, adjusted; MSE, mean squared error; Coef. Coefficient; Std. Err., standard error; $t$, - statistic; $P, p$-value; Conf., confidence; Jobfam, job family; Indust, industry; cons, consolidated.

FIGURE 2: Regression model of annual income, gender, race, job family and industry.

R137 865.10; secretarial earn less R189 013.50; and Technical and Specialist earn less by R46 480.14.

The model further predicted guaranteed package by industry using distributive services as a reference point. The predicted relative earning to distributive service were as follows: extractive pay less by R26 778.88; personal services pay less by R8440.82; producer services pay more by R24 835.18; social services pay more by R13 240.43; and transformative pay more by $\mathrm{R} 123816.90$.

\section{Discussion}

This section is presented based on the research questions:

- What is the gender pay gap in salary bands or among employees performing similar work?

The investigation of equal pay for work of equal value and representation of women relative to men in salary bands revealed that there was an increase in the proportion of women relative to males in semi-skilled jobs, skilled jobs and the lower band of middle management jobs, while there was an increase in the proportion of men relative to women in the upper band of middle- to top management jobs. These findings support the observation of Gayle, Golan and Miller (2012) that women hold more junior positions and fewer executive management positions than men. The under-representation of women in high-paying management positions has been linked with the persistence of genderrelated labour market disparities in many countries (Hensvik, 2014).

The analysis of the gender pay gap within the salary bands was done from the point of view that respondents within a salary band performed similar duty or tasks. The statistically significant higher income of men compared to women in salary bands A, B, C, D and E-lower indicated that respondents who performed similar work were not similarly compensated. Among other factors, the significant difference in their income could be explained by discrimination and by occupational segregation.

The pay gap at the bottom and top of the pay distribution, corresponding to the unskilled and management levels, 
respectively, suggest the presence of a sticky floor and glass ceiling. The phenomena of the sticky floor and glass ceiling are associated with the gender pay gap at the bottom and senior levels, respectively (Addabbo \& Favaro, 2011; Miller, 2009; Van Kerm, 2013). Discrimination and the glass ceiling are known to play a pivotal role in the gender pay gap in South Africa (Folke \& Rickne, 2016; Steyn, 2012). Differences in negotiation skills could also play a role (Travis, 2014). Although men's pay was higher in salary band B with regards to the median, women's pay was higher than that of men at the 75th and 95th percentile, the topmost levels in the band. This could indicate presence of better-skilled women at higher grades within the band. Similar observations were reported by Ncube (2012).

In the present study, men and women in salary band $\mathrm{F}$ and sub-band E-upper were fairly compensated for similar work despite the pay gap. This could be explained by the presence of women with a high-level of education, which is known to narrow the gender pay gap (Aláez-Aller et al., 2011). This was indicated by the absence of a statistically significant difference in the pay of the men and women. Although not significant, the pay gap of $27.1 \%$ in F-upper stood out from the pay gaps in other salary bands, which were below $10.0 \%$. This could be because of the few observations in the band, which included only 2 women and 54 men.

- What is the effect of gender, race, job family and industry on the gender pay gap in the study population?

The statistically significant association of income with gender and race could be explained by a persistence of discrimination against women, occupational segregation and women's relatively lower accumulated human capital development. The proportion of men in the study sample is not consistent with the country's demographic of $51.3 \%$ women and $48.7 \%$ men reported in the 2011 census. The under-representation of women in the study population, compared to their representation in South Africa's population further point to presence of discrimination (Folke \& Rickne, 2016; Steyn, 2012). A similar observation was also reported by Steyn (2012), who stated that men are more likely to be employed, despite the fact that women constituted a large proportion of the working-age adults in South Africa. The finding was further corroborated by Wekwete (2014), who stated that the labour force participation of women is less than that of men and that more men than women work in the formal sector, where work is paid and supported by national policies.

Furthermore, the confirmed sustained under-representation of women in employment is a source of inequality. According to Steyn (2012), under-representation of women without logical reason suggests the presence of a form of discrimination. The higher representation of men was observed in all ethnic groups in the study sample. The figure was particularly high among black and white respondents. Discrimination, career choices and the inability of women to negotiate a lucrative income are known contributors to women's pay being lower than that of men (Hirsch, König, \& Möller, 2013; Wekwete, 2014).
Although females now have unrestricted access to education and human capacity development, their under-representation may be a result of the fact that currently the talent pool from which to select women to meet government's target of $50 \%$ representation of women in employment, especially at management level, is too small. This view is supported by the findings of the research published by Kahn and Motsoeneng (2014), who suggested that the shortage of women with suitable qualifications could be because of racial segregation practices of the past against black people and discrimination against women in general. Women opting for part-time jobs or unavailable for paid employments because they need to take care of their children, husband and extended family (Blau \& Kahn, 2007) and the high-level patriarchy in society may have played a role. Black women are worst affected as they are confronted by both racism and patriarchy.

The study sample was similar to South Africa's population in term of ethnicity representation, as it consisted of black people in the majority and Asian people the least. It differed in the number of white people, which was twice that of people of mixed race. According to the 2011 census, South Africa's population consisted of $79.2 \%$ black people, $8.9 \%$ white people, $8.9 \%$ mixed race people and $2.5 \%$ Asian people (Stats, 2012). The pay in the study sample also followed the trend observed in the South African population and reported in the 2011 census (Stats, 2012), where the income of white people was the highest, followed in descending order by Indian people, people of mixed race and black people. The Broad-based Black Economic Empowerment Act 53 of 2003 does not seem to have had a meaningful effect on the economic status of the black people. This status was confirmed by the population censuses of 2001 and of 2011 (Stats, 2012).

The statistically significant association of income with job family and industries suggests the presence of occupational segregation in the study sample. Although there is a statistically significant association between income and gender, race, job family and industry, the model could not explain $56.0 \%$ of the variance in annual income. This may be because of variables such as education, work experience and marital status missing in the model (Steyn, 2012; Steyn \& Jackson, 2015). These variables are essential for the model to better predict pay. The test for multicollinearity ruled out bias caused by multicollinearity on the output of the model.

\section{Limitations of this research}

Although the sample size was big, the study findings should be generalised with caution because the extent to which the study sample represents South African population is not certain. Moreover, bias because of missing values could not be completely ruled out.

\section{Future research}

There is a need to conduct a survey with sample size powered for findings generalisable to the South African population. Application of mixed methods should be useful for gaining a 
comprehensive understanding of findings. The status of the gender pay gap in job family and industry needs to be studied in detail.

\section{Management implications}

The government empowerment programme for women seems to be yielding promising results. Women are represented in all job categories including in senior to top management positions. This observation supports the findings of the study by Kahn and Motsoeneng (2014), which confirmed that the number of women in top management, senior management and skilled positions has increased. Although the gender pay gap persisted across the salary bands, a trend has developed and the pay of women was similar to that of men in senior and top management positions. Nevertheless, the goal of achieving gender equality stated in the constitution of South Africa and other legislation is still far from being achieved. For example, the black economic empowerment (BEE) programmes of government, the Employment Equity Act 47 of 2013, the White Paper on Affirmative Action in the Public Service of 1998 and the White Paper on Transformation in the Public Service of 1995 do not seem to have had a measurable effect on black people's income, as the status quo has remained unchanged, white people still earn the highest pay and black people the lowest. While women constitute over $50.0 \%$ of South Africa's adult population, they are still underrepresented in employment and in all salary bands, especially at senior and top management levels. Gender and race continue to determine the income of employees, showing that the Promotion of Equity and Prevention of Unfair Discrimination Act 4 of 2000 is yet to take full effect. The inadequate number of qualified women to meet the target of $50.0 \%$ representation of women in senior management positions points to a continued shortage in human capital development among women (Kahn \& Motsoeneng, 2014). Therefore, priority should be given to fighting discrimination, supporting training and development, and providing women with better access to career development.

\section{Recommendations}

As the gender pay gap persists widely, all existing policies and legislation need to be reviewed and revised where necessary. Implementation programmes for the legislation need to be developed and actively monitored for compliance. According to Kahn and Motsoeneng (2014), equality legislation, regulations and policies are good, but more active measures to monitor their implementation are required. Compliance with equity policies and legislation should no longer be voluntary and should be monitored actively (Saari, 2013; Smith, 2010). Penalties for non-compliance should be instituted to discourage violation of such policies and legislation (Kahn \& Motsoeneng, 2014), while compliance should be rewarded. Furthermore, there is need to continue empowering women's human capital resources and career capital development in term of education and access to quality employment and career opportunities. This is necessary in order to develop enough competent women that can participate in the labour force and occupy management positions. The targeted interventions should also be extended to black people, people of mixed race and Asian and Indian people as a whole, women and men. This approach will assist to prevent unintended and negative consequences such as marginalisation of the men in the affected population groups (Kahn \& Motsoeneng, 2014). It is also necessary to develop and implement policy that will accommodate the societal role of a women as a caregiver and wage worker (Zebracki, 2014). This will be essential if women who have started a family are to be attracted and retained in the work force, without having to choose between their paid job and family responsibilities including the care of their children, husband and extended family (Nadler \& Stockdale, 2012), as well as to avoid the consequence referred to as the 'motherhood penalty'. The motherhood penalty is when mothers earn significantly less than childless women with the same characteristics (Misra \& Strader, 2013).

\section{Conclusion}

Government intervention to empower women seems to be yielding promising results. Women are represented in all salary bands or job categories. However, the gender pay gap is present in all salary bands and is statistically significant except at salary bands E and F, corresponding to the senior management and top management levels, where the pay gap is converging to similar pay for similar work. Furthermore, the number of women is smaller compared to their male counterparts in all salary bands, most especially in senior management and top management positions. The annual income is dependent on gender, race, job family and industry. The gender pay gap can be attributed to discrimination, occupational segregation and educational or skills level. There is need to review the existing policies and legislation. The implementation of the policies and legislation also needs to be reviewed and possibly revised. There is need to consider developing a new policy to cater for the dual roles of women as a caregiver and a wage worker. Finally, a broad-based approach that caters for the needs of both men and women, with relevance to race, is needed to ensure the effectiveness of interventions in order to close the gender pay gap.

\section{Acknowledgements Competing interests}

The authors declare that they have no financial or personal relationships that may have inappropriately influenced them in writing this paper.

\section{Authors' contributions}

A.A. was responsible for the project design and analysis. M.H.R.B. made intellectual and conceptual contributions. A.A. and M.H.R.B. co-wrote the manuscript.

\section{References}

Addabbo, T., \& Favaro, D. (2011). Gender wage differentials by education in Italy. Applied Economics, 43(29), 4589-4605. https://doi.org/10.1080/00036846.2010.491475

Aláez-Aller, R., Longás-García, J. C., \& Ullibarri-Arce, M. (2011). Visualising gender wage differences in the European Union. Gender, Work \& Organization, 18, e49-e87. https://doi.org/10.1111/j.1468-0432.2009.00469.x 
Arnania-Kepuladze, T. (2012). Disparity in the employment sphere: The measurement of pay gender disproportion. Problems of Management in the 21st Century, 3 , of pay
$20-25$.

Arulampalam, W., Booth, A. L., \& Bryan, M. L. (2007). Is there a glass ceiling over Europe? Exploring the Gender pay gap across the wage distribution. Industrial \& Labor Relations Review 60(2), 163-186. https://doi.org/10.1177/001979390706000201

Arvanitis, S. E., Stamatopoulos, T. V., \& Thalassinos, E. I. (2009). Gender wage gap: Evidence from the Hellenic Maritime Sector 1995-2002. Bulletin of the Transilvania University of Brasov. Series V: Economic Sciences, 2, 197-206.

Belgorodskiy, A., Crump, B., Griffiths, M., Logan, K., Peter, R., \& Richardson, H. (2012). The gender pay gap in the ICT Labour Market: Comparative Experiences from the UK and New Zealand. New Technology, Work \& Employment, 27(2), 106-119. https://doi.org/10.1111/j.1468-005X.2012.00281.x

Bendl, R., \& Schmidt, A. (2013). Gender mainstreaming: An assessment of its conceptual value for gender equality. Gender, Work \& Organization, 20(4), 364-381. https:// doi.org/10.1111/j.1468-0432.2011.00584.x

Bhorat, H., \& Goga, S. (2013). The gender wage gap in post-apartheid South Africa: A re-examination. Journal of African Economies, 22(5), 827-848. https://doi.org/ 10.1093/jae/ejt008

Blau, F. D., \& Kahn, L. M. (2007). The gender pay gap: Have women gone as far as they can? Academy of Management Perspectives, 21(1), 7-23. https://doi.org/10.5465/ can? Academy of Manag
AMP.2007.24286161

Bosch, A. (2015). Reasons for the gender pay gap - What HR practitioners should know. In A. Bosch (Ed.), South African board for people practices women's Report 2015 (pp. 3-6). Parktown, South Africa: SABPP.

Bussin, M., Nicholls, M., \& Nienaber, R. (2016). The relationship between occupational culture dimensions and reward preferences: A structural equation modelling approach: Original research. SA Journal of Human Resource Management, 14(1), 1-12. https://doi.org/10.4102/sajhrm.v14i1.737

Bussin, M., \& Nienaber, R. (2015). The gender pay Aap - A boardroom perspective. In A. Bosch (Ed.), South African Board for people practices women's Report 2015 (pp.13-17). Parktown, South Africa: SABPP.

Casale, D., \& Posel, D. (2011). Unions and the gender wage gap in South Africa. Journal of African Economies, 20(1), 27-27. https://doi.org/10.1093/jae/ejq029

Creswell, J. W. (2013). Research design: Qualitative, quantitative, and mixed methods approaches. California: Sage Publications.

de Jonge Oudraat, C., 2013, UNSCR 1325 - Conundrums and opportunities. International Interactions, 39(4), 612-619. https://doi.org/10.1080/03050629.20 International
13.805328

Drolet, M., \& Mumford, K. (2012). The gender pay gap for private-sector employees in Canada and Britain. British Journal of Industrial Relations, 50(3), 529-553. https:// doi.org/10.1111/j.1467-8543.2011.00868.x

Folke, O., \& Rickne, J. (2016). The glass ceiling in politics. Comparative Political Studies, 49(5), 567-599. https://doi.org/10.1177/0010414015621073

Fransen, E., Plantenga, J., \& Vlasblom, J. D. (2012). Why do women still earn less than men? Decomposing the Dutch gender pay gap, 1996-2006. Applied Economics, 44(33), 4343-4354. https://doi.org/10.1080/00036846.2011.589818

Gayle, G. -L., Golan, L., \& Miller, R. A. (2012). Gender differences in executive compensation and job mobility. Journal of Labor Economics, 30(4), 829-871. https://doi.org/10.1086/666615

Hensvik, L. E. (2014). Manager impartiality: Worker - Firm matching and the gender wage gap. Industrial \& labor relations review, 67(2), 395-421. https://doi.org/ 10.1177/001979391406700205

Hirsch, B., König, M., \& Möller, J. (2013). Is There a gap in the gap? Regional differences in the gender pay gap. Scottish Journal of Political Economy, 60(4), 412-439. in the gender pay gap. Scottish Journ
https://doi.org/10.1111/sjpe.12017

Jefferson, T., \& Austen, S. (2015). Understanding links between gender and pay: An important role for heterodox economics. Journal of Australian Political Economy, 75, 115-132.

Kahn, S. B., \& Motsoeneng, R. P. (2014). Gender equality in the South African public service: Ideal or reality? Journal of Public Administration, 49(4), 1060-1082.

Luci, A., Jütting, J., \& Morrisson, C. (2012). Why do so many women end up in 'Bad Jobs'? A cross-country assessment for developing countries. The European Journal of Development Research, 24(4), 530-549. https://doi.org/10.1057/ejdr.2011.54

Mandel, H., \& Semyonov, M. (2014). Gender pay gap and employment sector: Sources of earnings disparities in the United States, 1970-2010. Demography, 51(5), 1597-1618. https://doi.org/10.1007/s13524-014-0320-y

McCusker, K., \& Gunaydin, S. (2015). Research using qualitative, quantitative or mixed methods and choice based on the research. Perfusion, 30(7), 537-542. https:// doi.org/10.1177/0267659114559116
Miller, P. (2009). The gender pay gap in the US: Does sector make a difference? Journal of Labor Research, 30(1), 52-74. https://doi.org/10.1007/s12122-0089050-5

Misra, J., \& Strader, E. (2013). Gender pay equity in advanced countries: The role of parenthood and policies. Journal of International Affairs, 67(1), 27-41.

Nadler, J. T., \& Stockdale, M. S. (2012). Workplace gender bias: Not just between strangers. North American Journal of Psychology, 14(2), 281-291.

Ncube, P. (2012). An empirical investigation of the gender wage gap in South Africa. Master of Commerce, University of Johannesburg. Retrieved from http://iippe. org/wp/wp-content/uploads/2013/06/Ncube-Tregenna-IIPPE-2013.pdf

New Joint Committee for Higher Education Staff (JNCHES). (2011). The gender pay gap: A literature review. Retrieved from http://ucea.ac.uk/en/publications/index. $\mathrm{cfm} /$ njgpygap

O'Dorchai, S. (2011). The gender pay gap in research: A comparison of 23 European Countries. Brussels economic review, 54(2/3), 237-275.

Pagano, M., Gauvreau, K., \& Pagano, M. (2000). Principles of biostatistics, vol. 2. Pacific Grove, CA: Duxbury.

Rego Diaz, V. (2013). Historical-Critical dictionary of marxism. Historical Materialism, 21(3), 247-250.

Rollor, C. R. (2014). Narrowing the gender pay gap by providing equal opportunities: The need for tenured female professors in higher STEM institutions in an effort to recast gender norms. UCLA Women's Law Journal, 21(2), 143-184.

Rosner, B. (2015). Fundamentals of biostatistics. Boston, MA: Cengage Learning.

Saari, M. (2013). Promoting gender equality without a gender perspective: Problem representations of equal pay in Finland. Gender, Work \& Organization, 20(1), 36-55. https://doi.org/10.1111/j.1468-0432.2011.00554.x

Saunders, J. A., Morrow-Howell, N., Spitznagel, E., Doré, P., Proctor, E. K., \& Pescarino, R. (2006). Imputing missing data: A comparison of methods for social work researchers. Social work research, 30(1), 19-31. https://doi.org/10.1093/ swr/30.1.19

Saunders, M., \& Lewis, P. (2012). Doing research in business and management: An essential guide to planning your project. London: Pearson Education.

Smith, M. (2010). The gender pay gap in the EU-What policy responses?, Analysis Note, DG Employment. Social Affairs and Equal Opportunities.

StataCorp, L. (2015). STATA 14 [Computer software]. College Station, TX: StataCorp LP.

Stats, S. (2012). Census 2011, Statistical Release (Revised) P0301. 4. Pretoria: Statistics South Africa, Retrieved from http://www.statssa.gov.za/PublicationsP,3014

Steyn, R. (2012). Expanding the suite of measures of gender-based discrimination: Gender differences in ablution facilities in South Africa. South African Journal of Economic and Management Sciences, 15(2), 222-234. https://doi.org/10.4102/ sajems.v15i2.212

Steyn, R., \& Jackson, L. (2015). Gender-based discrimination in South Africa: A quantitative analysis of fairness of remuneration. South African Journal of Economic and Management Sciences, 18(2), 190-205. https://doi.org/10.17159/2222-3436/ 2015/v18n2a4

Travis, M. A. (2014). Disabling the gender pay gap: Lessons from the social model of disability. Denver University Law Review, 91(4), 893-923.

Twenty-first-(21st)-Century-Pay-Solutions. (2016). Paterson job evaluation guiding principles. Retrieved from http://www.21century.co.za

Van Kerm, P. (2013). Generalized measures of wage differentials. Empirical Economics, 45(1), 465-482. https://doi.org/10.1007/s00181-012-0608-y

Wegner, T. (2012). Applied business statistics: Methods and Excel-based applications (3rd edn.). Cape Town: Juta and Company.

Wekwete, N. N. (2014). Gender and economic empowerment in Africa: Evidence and policy. Journal of African Economies, 23(suppl 1), i87-i127. https://doi.org/10.1093/ jae/ejt022

Witkowska, D. (2013). Gender disparities in the labor market in the EU. International Advances in Economic Research, 19(4), 331-354. https://doi.org/10.1007/s11294 013-9431-2

$\mathrm{Xu}, \mathrm{Y}$. (2015). Focusing on women in STEM: A longitudinal examination of gender-based earning gap of college graduates. Journal of Higher Education, 86(4), 489-523. https://doi.org/10.1353/jhe.2015.0020

Zebracki, M. (2014). Sex in the city: Gender mainstreaming urban governance in Europe. The case of Sweden and Italy. Fennia, 192(1), 55-64. https://doi.org/ 10.11143/7894

Zikmund, W. G., Babin, B. J., Carr, J. C., \& Griffin, M. (2013). Business research methods. Boston, MA: Cengage Learning. 